\title{
Wetland edges as peak refugia from an introduced piscivore
}

\author{
ANDREA J. REID ${ }^{\mathrm{a}, \mathrm{b}, *}$, LAUREN J. CHAPMAN ${ }^{\mathrm{a}, \mathrm{c}}$ and ANTHONY RICCIARDI ${ }^{\mathrm{a}, \mathrm{b}}$

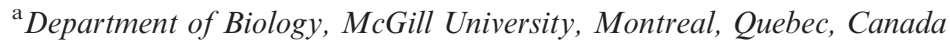 \\ ${ }^{\mathrm{b}}$ Redpath Museum, McGill University, Montreal, Quebec, Canada \\ ${ }^{\mathrm{c}}$ Wildlife Conservation Society, Bronx, New York, USA
}

\begin{abstract}
1. Wetlands in the Lake Victoria basin serve as structural and hypoxic refugia for some native fishes against predation by introduced Nile perch (Lates niloticus); however, little is known about the fine-scale patterns of distribution and abundance of these refuge inhabitants.

2. This study sought to quantify wetland ecological gradients and determine where peaks in native fish abundance and richness ('peak refugia') occurred using Lake Nabugabo, Uganda as a model system.

3. Extensive wetland transects were sampled between June and August, 2011 to measure ecological variation over distance from the lake-wetland edge.

4. Wetlands were characterized by strong clines in water temperature, $\mathrm{pH}$, dissolved oxygen (DO), depth and vegetation density, and narrow peak refugia were found precisely at the lake-wetland edge. Community richness and diversity tended to be greater in areas with higher DO and lower temperature, $\mathrm{pH}$, and vegetation density. It is interesting that areas encroached upon by a native emergent macrophyte (hippo grass, Vossia cuspidata) had more extreme physico-chemical conditions and supported fewer native fish species.

5. These results demonstrate the importance of wetland edges in the maintenance of native fish fauna in the Lake Victoria basin, and suggest that the continued expansion of hippo grass may reduce the accessibility of wetlands as refugia.

6. We recommend that the use of spatially explicit management approaches such as the development of secure buffer zones surrounding wetland edges to protect peak refugia, and the need for hippo grass control to minimize its effects on this important refuge.

Copyright (C) 2013 John Wiley \& Sons, Ltd.
\end{abstract}

Received 08 July 2012; Revised 03 December 2012; Accepted 06 December 2012

KEY WORDS: wetland; conservation evaluation; Ramsar site; taxon richness; fish; alien species

\section{INTRODUCTION}

The rate, magnitude, and frequency of modern biological invasions is unprecedented in Earth's history (Ricciardi, 2007). Ecologists are searching for ways to predict and manage the impacts of invasive species, but this has been a challenging task with varying results to date. Much research has focused on terrestrial habitats (Courchamp et al., 2003; Levine et al., 2003); however, freshwater animals are disappearing at a rate several times faster than land animals (Ricciardi and Rasmussen, 1999), and invasions are recognized as a major cause of extinction (Sala et al., 2000; Clavero and Garcia-Berthou, 2005). Introduced predators have had particularly devastating impacts on native taxa in lakes (Zaret and Paine, 1973; Hall and Mills, 2000; Trumpickas et al., 2011), largely owing to the insularity of these freshwater systems and the evolutionary naiveté of their biota (Cox and Lima, 2006).

*Correspondence to: A. J. Reid, Department of Biology, McGill University, 1205 Docteur Penfield, Montreal, Quebec H3A 1B1, Canada. E-mail: andrea.reid2@mail.mcgill.ca 
To predict and manage the impacts of introduced predators ecologists must identify ecosystem qualities that inhibit predation and/or create distributional barriers for the predator (Rosenberger and Chapman, 1999). Areas outside these boundaries may be exploited by native species as refugia to reduce the risk of predation (Crowder and Cooper, 1982; Ayala et al., 2007). Refugia populations may consist of remnants of larger communities that were widespread before predator introduction, or they may comprise native species that have shifted their distributions into areas where the invader is less abundant. As an example of the latter, the native galaxiid fish (Galaxias olidus) in south-eastern Australia escapes predation from introduced brown trout (Salmo trutta) by shifting into headwater streams where low flow and high temperatures inhibit trout dispersal and colonization (Closs and Lake, 1996). It is interesting that the edge between refuge and invaded habitats is a potentially critical area characterized by gradients in physico-chemical and biological features to which the invader and native species respond differentially (Kestrup and Ricciardi, 2009). Thus, the relationship between edge-related gradients and predator-prey abundances should determine where refugia support the highest abundance and richness of prey, termed 'peak refugia' (Figure 1). If native species are more tolerant of refuge conditions than the invader, there may be some distance from the refuge edge where predator-prey encounters are minimized, but beyond which conditions become less hospitable and limit prey abundance or fitness. Although several studies have demonstrated the importance of refugia in mediating

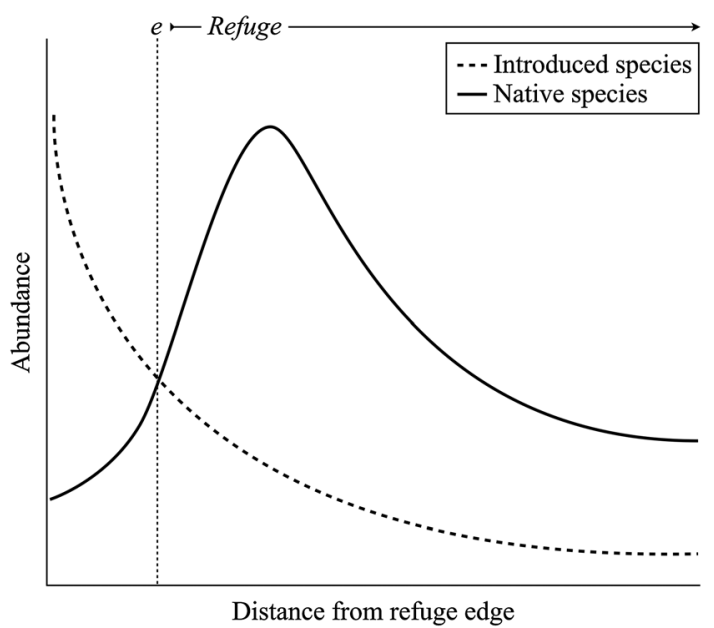

Figure 1. Identifying peak refugia. Peaks in native species abundance occur some distance from the refuge edge (indicated by the dotted reference line and the symbol $e$ ) where introduced species abundance is minimized. invasive predator and native prey interactions, the development of a general theory of invader-edge dynamics is in its infancy, but is essential for informing conservation management decisions.

This study contributes to the development of invader-edge theory by testing the peak refugia hypothesis in wetland habitats of the Lake Victoria basin, East Africa, where a subset of the native fauna persists under reduced predation pressure from introduced Nile perch (Lates niloticus). Over the past century, this system has experienced severe overfishing, widespread eutrophication and several species introductions, including Nile tilapia (Oreochromis niloticus) and Nile perch (reviewed by Balirwa et al., 2003; Chapman et al., 2008). As a result, hundreds of native fishes declined or disappeared (Kaufman, 1992; Ogutu-Ohwayo, 1993); however, some species persisted by occupying refugia such as satellite lakes (Ogutu-Ohwayo, 1993), rocky habitats (Witte et al., 1992; Seehausen, 1996; Seehausen et al., 1997), and principally wetlands (Chapman et al., 1996a, b; Rosenberger and Chapman, 1999). For instance, in satellite Lake Nabugabo, more than half of the native fishes extirpated from the main lake were recovered inside wetlands (Chapman et al., 1996b). Wetlands serve as structural and low-oxygen (or 'hypoxic') refugia by functioning as a barrier to Nile perch dispersal. In contrast with many native fishes (e.g. haplochromine cichlids) Nile perch can reach a very large size (maximum length $=200 \mathrm{~cm}$ ) and are relatively intolerant of hypoxic conditions (Schofield and Chapman, 2000; Chapman et al., 2002); they are thus both physically and physiologically excluded from wetlands. Initial studies found more native species inhabiting the ecotone at the lake-wetland edge, where oxygen is moderately low (mean $3.8 \mathrm{mg} \mathrm{L}^{-1}$ ), than areas deep within the hypoxic swamp interior (mean $1.3 \mathrm{mg} \mathrm{L}^{-1}$; Chapman et al., 1996a, b). The ecotone appears to be a very diffuse boundary, and interaction with the main lake creates potentially steep physico-chemical gradients between the ecotone and deep interior, yet how the wetland edge affects this refuge remains unexplored. The aim of this study is to quantify edge-related gradients and identify peak refugia using the wetlands of Lake Nabugabo as a model system.

The Lake Nabugabo system is used for three primary reasons: (i) Lake Nabugabo $\left(33 \mathrm{~km}^{2}\right)$ is much smaller than Lake Victoria $\left(68800 \mathrm{~km}^{2}\right)$ and can thus be more thoroughly sampled; (ii) it has a 
long history of ecological research that chronicles the Nile perch invasion and faunal collapse (Fish, 1956; Greenwood, 1965; Ogutu-Ohwayo, 1993); and (iii) it has been the primary site of wetland refugia studies in the basin (Chapman et al., 1996a, b, 2002, 2003; Rosenberger and Chapman, 1999; Schofield and Chapman, 1999), which facilitates temporal comparisons. An understanding of invader-edge dynamics is particularly critical at this time as ecological changes in the wetland ecotones of Lake Nabugabo and other lakes of the Victoria basin may alter refuge dynamics. Over the past decade, there has been rapid expansion of a native emergent macrophyte (hippo grass, Vossia cuspidata) from a few sparse stands to now dominating 70\% of the wetland edge (Kateyo, 2006; Paterson and Chapman, 2009). Over the same time period there has been an increase in the number of small Nile perch $(<20 \mathrm{~cm}$ TL) occupying nearshore wetland habitats (5-20 m offshore), which may be selecting for more wetland-resistant Nile perch, and thereby increasing the potential for predator-prey encounters near wetland ecotones (Paterson and Chapman, 2009).

\section{METHODS}

\section{Study area}

Lake Nabugabo is a shallow satellite lake (mean depth $4.5 \mathrm{~m}$ ) of Lake Victoria, located at $1136 \mathrm{~m}$ elevation in southern Uganda $\left(00^{\circ} 24^{\prime} \mathrm{S}, 031^{\circ} 54^{\prime} \mathrm{E}\right.$; Figure 2(a)). It became isolated from Lake Victoria through the formation of longshore bars during lake level fluctuations approximately 5000 years ago (Stager et al., 2005). The main tributaries to Lake Nabugabo are the Juma River and numerous small springs, and the outflow towards Lake Victoria passes through the vegetated sandbar (maximum width $3.8 \mathrm{~km}$ ) that separates the main lakes (Greenwood, 1965). The extensive Lwamunda Swamp $\left(22 \mathrm{~km}^{2}\right)$ surrounding Lake Nabugabo was designated as a Ramsar site in 2004 for its importance in maintaining endemic fish diversity, rare floral species, and threatened migratory birds (Bikangaga et al., 2007). The wetland is dominated by a floating platform of Miscanthidium violaceum (hereafter 'Miscanthidium'), and the ecotone is vegetated by a combination of Miscanthidium, hippo grass, water-lilies (Nymphaea caerulea and Nymphaea lotus), and papyrus (Cyperus papyrus; Kateyo, 2006). Before the 1990s, hippo grass was present only in small stands in sheltered bays and

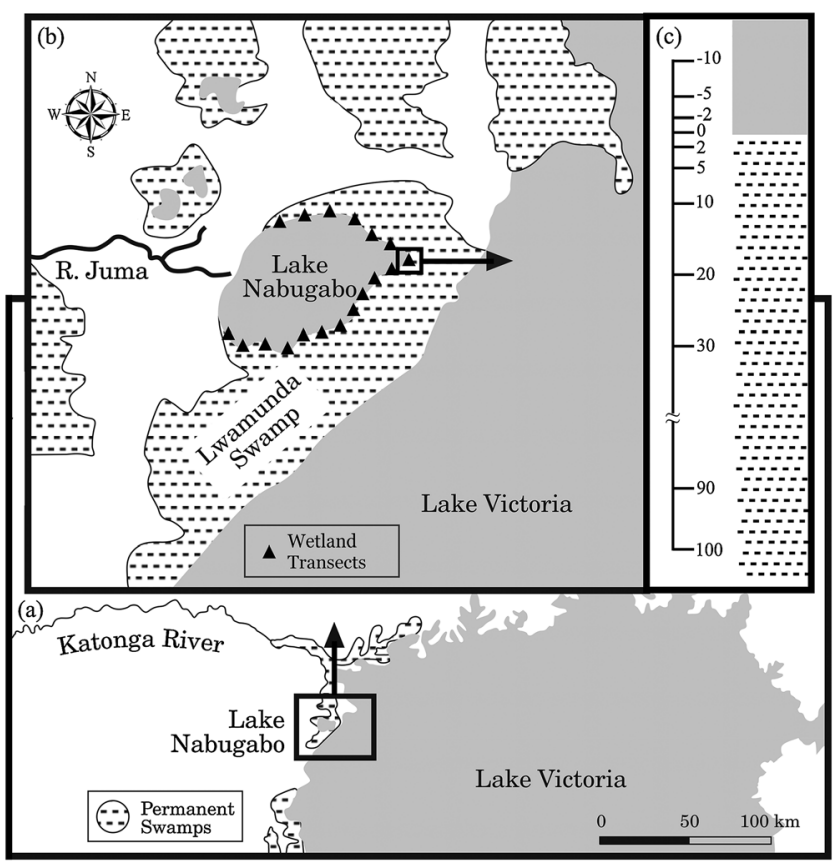

Figure 2. Map of Lake Nabugabo, Uganda (adapted from Rosenberger and Chapman, 2000). Panel (a) shows the location of Lake Nabugabo relative to Lake Victoria; (b) illustrates the distribution of wetland transects across Lake Nabugabo's Lwamunda Swamp; and (c) illustrates the location of trap sampling sites along each transect with reference to distance $(\mathrm{m})$ from the lake-wetland edge (negative values correspond to offshore sites and positive values correspond to wetland sites).

inlets (Greenwood, 1965), but it has since formed a thick margin (maximum width $70 \mathrm{~m}$ ) that is firmly anchored to the Miscanthidium platform around $70 \%$ of the wetland edge (Paterson and Chapman, 2009); the windward, northern shoreline remains largely devoid of hippo grass (Kateyo, 2006).

Changes in Lake Nabugabo's fish community were dramatic following the introduction of 85 Nile perch in 1960, and another 180 in 1963 (Ogutu-Ohwayo, 1993). In 1962, the Cambridge Nabugabo Biological Survey (unpublished data) catalogued the native fish species in the main lake and found 20 species of non-cichlids (e.g. Protopterus aethiopicus, Bagrus docmak, Schilbe intermedius, and Clarias gariepinus), eight haplochromine cichlids, of which five were endemic, and two tilapiine cichlids (Oreochromis esculentus and Oreochromis variabilis). By the early 1990s, most native fish species had either declined or disappeared from the open waters (Ogutu-Ohwayo, 1993). The fishery had shifted from a multi-species system ( $P$. aethiopicus, B. docmak, $S$. intermedius, $C$. gariepinus, $O$. esculentus, $O$. variabilis and haplochromine cichlids were the primary commercial catches) to principally targeting only three species: introduced Nile perch and Nile tilapia, and native Rastrineobola argentea (Cambridge Nabugabo Biological Survey, unpublished data; Ogutu-Ohwayo, 
1993). Studies in the mid-1990s, however, revealed that of the 16 known species extirpated from the main lake, three persisted in wetland ecotones (Barbus magdalenae, Clarias alluaudi, and Clarias werneri), three were found in the deep swamp interior (Barbus radiatus, Ctenopoma muriei and Petrocephalus catostoma), and three were found in both habitats (Aplocheilichthys pumilus, Barbus apleurogramma, and Pseudocrenilabrus multicolor; Chapman et al., 1996b).

\section{Sampling design}

Between June and August 2011, wetland transects $(n=18)$ were selected to maximize coverage of the wetland periphery and were separated by a minimum distance of $500 \mathrm{~m}$ (Figure 2(b)). Transects were sampled in random order, and they extended perpendicular to the shoreline from $10 \mathrm{~m}$ offshore to $100 \mathrm{~m}$ into the wetland habitat from the lake (with offshore sites represented by negative distance values, and wetland sites represented by positive distance values). The 'edge' was operationally defined as the lakeward border of the wetland, the 'ecotone' as the habitat extending $5 \mathrm{~m}$ on either side of the edge, and the 'interior' as all habitat inshore from the ecotone. Unbaited standard minnow traps (length: $43 \mathrm{~cm}$; diameter: $18 \mathrm{~cm}$; mesh size: $64 \mathrm{~mm}$ ) were systematically set along each transect at $10 \mathrm{~m}$ intervals, with additional traps placed at $2 \mathrm{~m}$ and $5 \mathrm{~m}$ on either side of the edge, producing a total of 16 traps per transect (Figure 2(c)). Traps were tied to emergent vegetation to remain at the air-water interface and allow surfacing behaviours (e.g. aquatic surface respiration, ASR) to prevent fish mortality. Although this gear type introduces a potential size bias (capturing fish $2-40 \mathrm{~cm}$ TL in the Lwamunda Swamp; L. Chapman, unpublished data), larger fishes are rare in these habitats owing to the extremely dense vegetative structure. Also, this quantitative sampling was used to compare species abundances and richness over distance from the wetland edge, not to produce absolute density estimates. Traps were set mid-morning (8:00-11:00) at which time data on the environmental and physical characteristics of each trap sampling site were recorded. Traps were retrieved $24 \mathrm{~h}$ later and data on the fish captured in each trap were collected.

The width of the hippo grass band $(\mathrm{m})$ was measured for each transect, and the following environmental data were recorded at each trap sampling site: distance from the wetland edge (m), water temperature $\left({ }^{\circ} \mathrm{C}\right), \mathrm{pH}$, a rank of the vegetation density ( $0-4)$, dissolved oxygen content (DO; $\mathrm{mg} \mathrm{L}^{-1}$ ), and water depth (m). Temperature and DO were measured using a portable meter (OxyGuard Handy Polaris) and $\mathrm{pH}$ with a handheld tester (HANNA model HI 98129) in the upper $10 \mathrm{~cm}$ of the water column. Diel variation in DO is generally low in the dense interior of the Lwamunda Swamp; for swamp pools at the landward side of the Lwamunda swamp, Reardon and Chapman (2008) reported DO (1 year of monthly samples) that averaged $1.1 \mathrm{mg} \mathrm{L}^{-1}$ in the morning and $2.6 \mathrm{mg} \mathrm{L}^{-1}$ in the afternoon. Because of the low diel variation in DO and the logistics of traversing through the swamp interior, sampling took place only in the morning, which should reflect the lower range of the daily variation. Characteristics of the vegetation and water availability were used to rank the vegetation density at each site; a site characterized by dense vegetation and low water availability was given the highest rank (4), while a site with sparse vegetation and high water availability was given the lowest rank (0).

All fish captured were identified in situ to the lowest taxonomic category possible and were released alive at the site of capture. Endemic haplochromine cichlids (which may include Astatotilapia velifer, Gaurochromis simpsoni, Haplochromis annectidens and Paralabidochromis beadlei) and clariid catfishes (Clarias alluaudi and Clarias liocephalus) could not be reliably distinguished in the field and were thus grouped as 'endemic haplochromines' and 'Clarias sp.', respectively. The number of fish captured in each trap over the $24 \mathrm{~h}$ period, the catch per unit effort (CPUE), was used as an index of fish abundance.

\section{Data analysis}

Variation in fish community structure was examined by calculating species relative abundance as a percentage of the total fishes captured in open water, ecotone, and interior habitats. Edge-related gradients and peak refugia were quantified by calculating the mean value for the following variables at each trap sampling site across transects: temperature, $\mathrm{pH}$, ranked vegetation density, DO, depth, and native species CPUE and richness. For wetland community-level analyses, mean values were calculated for each physico-chemical parameter across the interior habitat; to meet the 
assumptions for the statistical analysis, mean DO values were log-transformed for analysis and presentation. To identify significant physico-chemical predictors of community-level parameters, linear regressions were performed using mean temperature, $\mathrm{pH}$, ranked vegetation density, $\mathrm{DO}$ and depth as independent variables, and total native species richness and diversity (using Shannon's Diversity Index: $\left.H^{\prime}=-\sum_{i=1}^{S} p_{i} \log p_{i}\right)$ of the interior as response variables. Polynomial regressions were then performed to test for an effect of the width of the hippo grass band on the mean physico-chemical conditions and community-level parameters of the wetland interior. Multivariate approaches were not used because of the colinearity between variables such as temperature and DO (Chapman and McKenzie, 2009), and DO and vegetation density ('structural complexity'sensu Chapman et al., 1996a).

\section{RESULTS}

In total, 591 fishes were captured and identified along wetland transects; 26 were found in open water $(-10 \mathrm{~m}), 297$ in the ecotone $(-5 \mathrm{~m}$ to $5 \mathrm{~m})$ and 268 in the interior $(10-100 \mathrm{~m})$. The fish communities of these habitats differed in both composition and richness (Table 1).

Very few fishes were recovered in the open water probably due to the lower density of small fishes in offshore habitats. Ecotones contained nine species, with widespread and endemic haplochromines

Table 1. Relative abundance of fish species expressed as a percentage of total fishes captured in open water, ecotonal and interior wetland habitats

\begin{tabular}{|c|c|c|c|}
\hline & \multicolumn{3}{|c|}{ Relative abundance (\%) } \\
\hline & Open water & Ecotone & Interior \\
\hline \multicolumn{4}{|l|}{ Native species } \\
\hline Astatoreochromis alluaudi & 3.8 & 28.6 & 0.0 \\
\hline Barbus kerstenii & 0.0 & 0.0 & 3.4 \\
\hline Clarias sp. ${ }^{\mathrm{a}, \mathrm{b}}$ & 0.0 & 5.1 & 28.7 \\
\hline Ctenopoma muriei $^{\mathrm{a}}$ & 0.0 & 2.0 & 7.8 \\
\hline Endemic haplochromines ${ }^{c}$ & 92.3 & 45.1 & 0.0 \\
\hline Protopterus aethiopicus ${ }^{\mathrm{a}}$ & 0.0 & 0.0 & 1.1 \\
\hline Pseudocrenilabrus multicolor & 0.0 & 10.4 & 58.6 \\
\hline \multicolumn{4}{|l|}{ Introduced species } \\
\hline Lates niloticus & 0.0 & 0.3 & 0.0 \\
\hline Oreochromis leucostictus & 0.0 & 6.1 & 0.4 \\
\hline Oreochromis niloticus & 0.0 & 2.0 & 0.0 \\
\hline Tilapia rendalli & 3.8 & 0.3 & 0.0 \\
\hline
\end{tabular}

${ }^{\mathrm{a}}$ Air-breathing species.

${ }^{\mathrm{b}}$ Clarias sp. includes Clarias alluaudi and Clarias liocephalus.

${ }^{\mathrm{c}}$ Endemic haplochromines may include Astatotilpia velifer, Gaurochromis

simpsoni, Haplochromis annectidens and Paralabidochromis beadlei. accounting for $84.1 \%$ of the community, and introduced species totalling less than one-tenth $(8.7 \%)$ of the assemblage. Air-breathing species (indicated in Table 1) were rare in the ecotone (7.1\%), but accounted for half of the species present in the interior, and $37.6 \%$ of the fish abundance. Introduced species were absent from the interior (excepting the rare $O$. leucostictus), and the only haplochromine species present was $P$. multicolor, which made up more than half of the assemblage.

Acute physico-chemical gradients characterize the wetland habitats of Lake Nabugabo (Figure 3 (a)). Sampling revealed strong negative gradients in mean temperature, $\mathrm{pH}, \mathrm{DO}$ and depth with distance from the inshore from the wetland edge. In contrast, the vegetation density of sampling sites increased sharply between the offshore and wetland interior. Peaks in native species mean CPUE (8.5 fish per trap over $24 \mathrm{~h}$ ) and richness (1.7 species) occurred precisely at the wetland edge, and were consistently lower across offshore and interior sampling sites (Figure 3(b)).

Among wetland transects, temperature, $\mathrm{pH}$, vegetation density, and DO were significant predictors of native species richness and diversity of the wetland interior. Species richness was positively related to log-transformed mean DO $\left(\mathrm{R}^{2}=0.39, P=0.006\right.$; Figure 4(a)), and negatively related to mean temperature $\left(\mathrm{R}^{2}=0.30, P=0.019\right)$, mean $\mathrm{pH}\left(\mathrm{R}^{2}=0.32, P=0.014\right)$, and mean ranked vegetation density $\left(\mathrm{R}^{2}=0.79, P<0.001\right.$; Figure $\left.4(\mathrm{~b})\right)$. The same trends were observed using Shannon's Diversity Index (mean temperature: $\mathrm{R}^{2}=0.47$, $P=0.002$; mean $\mathrm{pH}: \mathrm{R}^{2}=0.47, P=0.003$; mean ranked vegetation density: $\mathrm{R}^{2}=0.51, P=0.001$; and mean DO: $\mathrm{R}^{2}=0.38, P=0.006$ ), but no community-level patterns emerged that were related to mean depth. Because increased vegetation density is associated with decreased DO $\left(\mathrm{R}^{2}=0.47\right.$, $P=0.002$ ), it is not possible to partition their independent effects on richness and diversity using a broad-scale analysis among transects. The width of the hippo grass band was negatively related to log-transformed mean DO $\left(\mathrm{R}^{2}=0.41, P=0.010\right.$; Figure 5(a)), and positively related to mean temperature $\left(\mathrm{R}^{2}=0.42, \quad P=0.005\right)$, mean $\mathrm{pH}$ $\left(\mathrm{R}^{2}=0.69, P<0.001\right)$ and mean ranked vegetation density $\left(\mathrm{R}^{2}=0.67, P<0.001\right.$; Figure $\left.5(\mathrm{~b})\right)$. Again, no patterns emerged that were related to mean depth. It is interesting that the width of the hippo grass band was a significant predictor of species richness $\left(\mathrm{R}^{2}=0.54, P=0.001\right.$; Figure $\left.5(\mathrm{c})\right)$ 

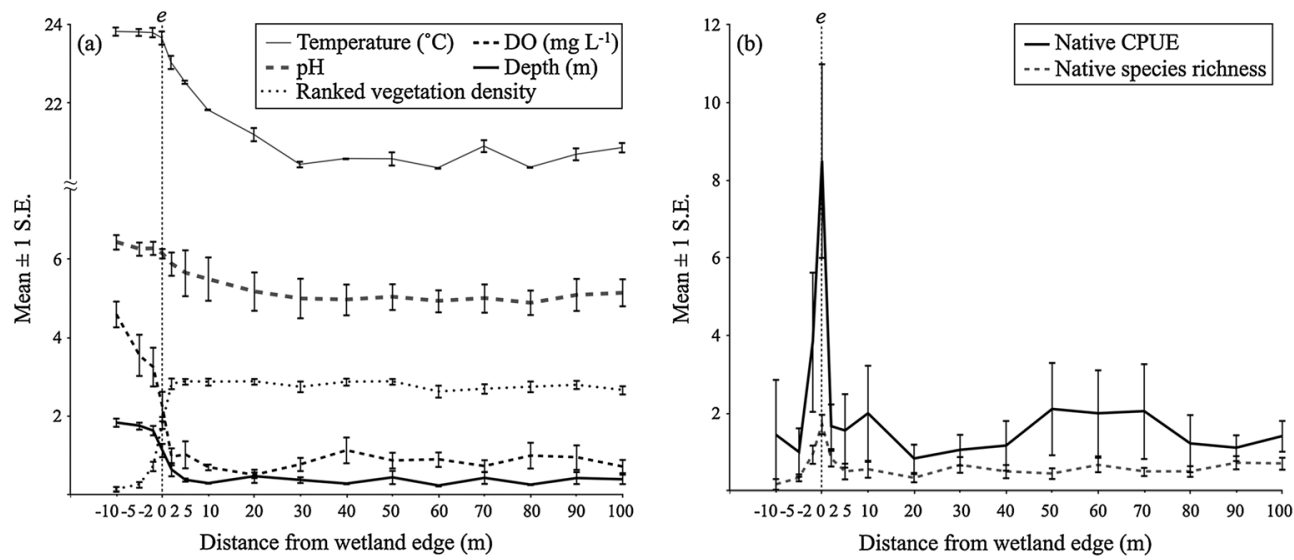

Figure 3. Edge-related gradients across the wetlands of Lake Nabugabo. Illustrated are the mean (a) physico-chemical conditions and (b) native fish species catch per unit effort (CPUE) and richness over distance from the wetland edge (indicated by the dotted reference line and the symbol $e$ ). Negative values correspond to offshore sites and positive values correspond to wetland sites. Standard error bars are shown.
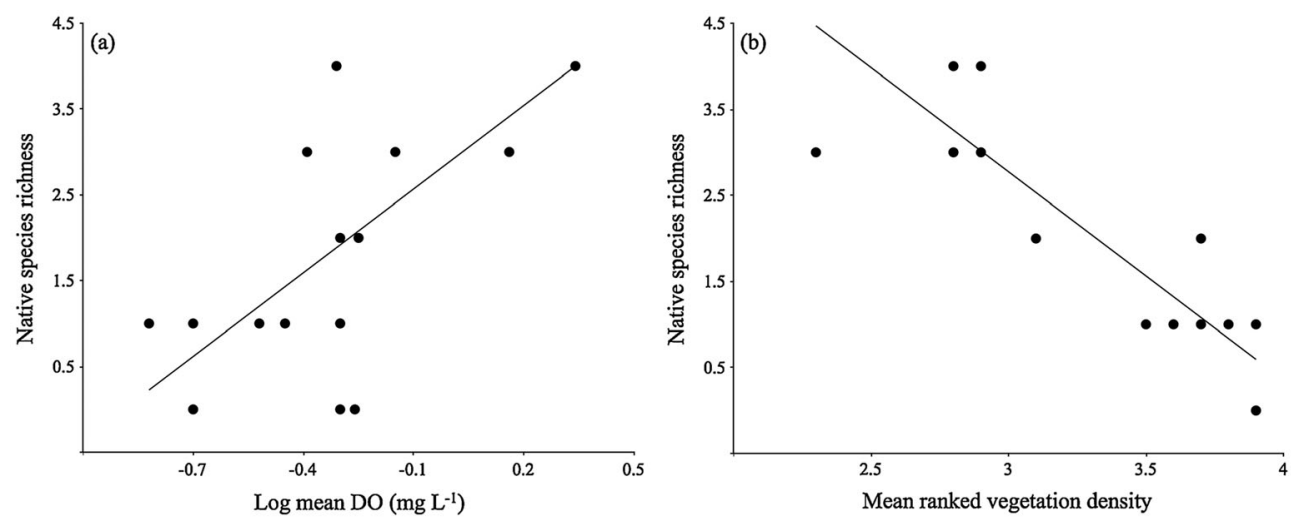

Figure 4. Relationships between native fish species richness and (a) log-transformed mean DO, and (b) mean ranked vegetation density of the wetland interior.

and diversity $\left(\mathrm{R}^{2}=0.41, P=0.005\right)$; both assemblage characteristics decreased with increasing width of hippo grass.

\section{DISCUSSION}

The lake-wetland edge of Lake Nabugabo provides an effective barrier to the dispersal of Nile perch and other introduced species into wetland habitats. These wetlands are characterized by strong edge-related gradients and narrow peak refugia. There were sharp declines in temperature, $\mathrm{pH}, \mathrm{DO}$, and depth, and an increase in vegetation density with distance inshore, and peaks in native fish abundance and richness occurred at the lakeward border of the wetland $(0 \mathrm{~m})$. Across the interior, species richness and diversity were negatively related to temperature, $\mathrm{pH}$, and vegetation density, and positively related to DO. Wetland areas with thicker margins of hippo grass had higher temperatures, $\mathrm{pH}$, and vegetation density, and lower DO, and thus supported a lower richness and diversity of native fish species.

\section{Invader-edge dynamics in Lake Nabugabo, Uganda}

In this study, peak refugia were found at the edge, rather than occurring at some distance from the edge of the refuge habitat, as predicted. This highlights the importance of the sharpness of refuge edges in determining the location of peak refugia. In areas where there is a sharp ecological transition between refuge and invaded habitats, invader abundance may attenuate rapidly, allowing native species to persist under reduced predation pressure only a small distance from the preferred habitat of the predator. If the transition is gradual, there may be a more progressive decline in invader abundance, causing peak refugia to occur further inside the refuge. The former is the case in Lake Nabugabo where this study found an acute ecological transition between lake and 

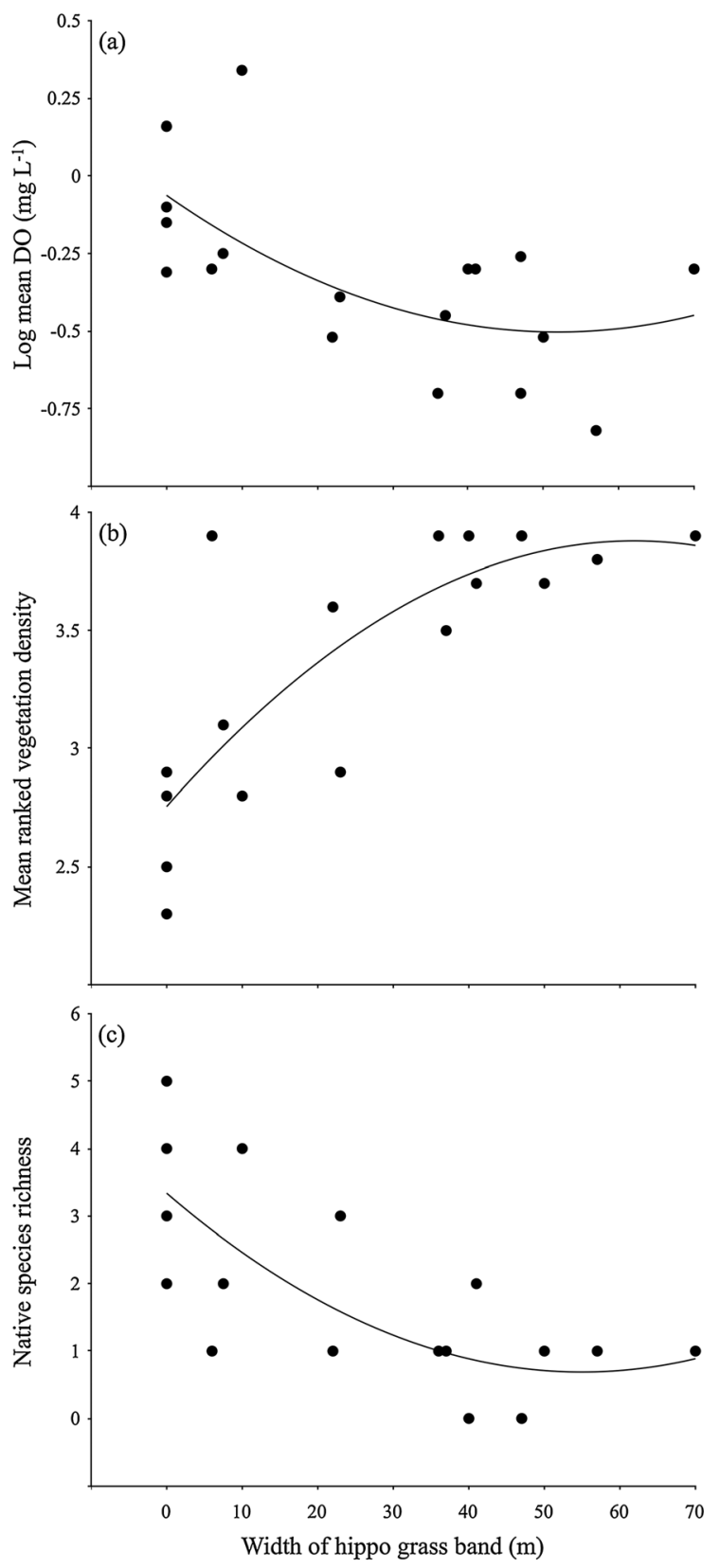

Figure 5. Relationships between (a) log-transformed mean DO, (b) mean ranked vegetation density, and (c) native fish species richness of the wetland interior and the width of the hippo grass band.

wetland habitats, and Nile perch were effectively excluded from wetland refugia; across the 288 trap sampling sites in this study, only a single Nile perch individual was recovered (at $0 \mathrm{~m}$ ). Similar patterns are observed in other systems where there is a hard edge between invaded and uninvaded habitats; for example, in their study of predation on hawksbill sea turtle (Eretmochelys imbricata) eggs by introduced mongooses (Herpestes javanicus), Leighton et al. (2008) demonstrated that peaks in hawksbill nest density occurred at the edge between the heavily invaded vegetation patches and the uninvaded open sand habitats. By occupying edge habitats, native prey species experience reduced predation pressure while benefitting from intermediate ecological conditions.

Peak refugia in Lake Nabugabo were also very narrow, extending less than $2 \mathrm{~m}$ on either side of the wetland edge. This suggests that the harsh physico-chemical conditions that characterize the wetland interior force lacustrine species into narrow, edgy habitats where conditions are most lake-like. Consistent with this idea, peak refugia were inhabited primarily by former lake-dwelling haplochromine species that exhibit low tolerance to interior conditions such as extreme hypoxia (e.g. A. alluaudi; Chapman and McKenzie, 2009). In contrast, the wetland interior harboured an assemblage of swamp specialists that inhabited wetlands before the Nile perch introduction (e.g. Clarias sp.; Greenwood, 1965). These species exhibit high tolerance to interior conditions (Chapman et al., 2002). Evidently, wetland inhabitants are spatially distributed according to their environmental tolerances (e.g. to hypoxic stress), which will thus determine their relative risk of encountering Nile perch. There is now growing empirical support from outside the Victoria basin demonstrating the value of hypoxic habitats as refugia for tolerant prey from less tolerant predators (Robb and Abrahams, 2003; Nilsson and Ostlund-Nilsson, 2004).

The near complete exclusion of Nile perch from wetland habitats suggests that the increasing number of small Nile perch occupying nearshore habitats is not conferring increased wetland resistance against present-day Nile perch populations, as proposed by Paterson and Chapman (2009). The findings of this study agree with previous evidence that Nile perch are intolerant of wetland conditions, allowing these habitats to serve as refugia for native fishes from Nile perch predation (Schofield and Chapman, 2000; Chapman et al., 2002).

\section{Hippo grass: friend or foe?}

The current expansion of hippo grass around the wetland perimeter of Lake Nabugabo was recently suggested to have stabilizing effects on introduced predator and native prey interactions (Paterson and Chapman, 2009). Based on data collected over a 12-year period (1995, 2000 and 2007), Paterson and Chapman (2009) found more haplochromines and Nile perch in lake habitats 
offshore from ecotones dominated by hippo grass than in areas where Miscanthidium formed the wetland edge. Based on their findings in the waters immediately offshore from hippo grass bands, they proposed that hippo grass simultaneously provides vegetation density that minimizes predation risk for haplochromines, and increases wetland penetrability for Nile perch while housing a high density of its preferred prey. However, sampling deep within wetland habitats in this study provided a much more in-depth understanding of hippo grass-fish interactions: a smaller number and diversity of native fishes persist in areas where hippo grass is thickest. In addition, this study found no evidence of increased accessibility for Nile perch as only a single individual was found in wetland habitats, which was recovered from the Miscanthidium edge; we suggest that hippo grass is actually reducing wetland accessibility for native fishes in terms of physico-chemical conditions. It is likely that the hippo grass band acts as a barrier to the movement of fish in and out of wetland habitats; patterns of fish dispersal across the hippo grass band is the subject of a related study (Reid and Chapman, unpublished).

Hippo grass is also encroaching upon wetland habitats in other lakes throughout the Victoria basin. For example, in the Nyanza and Napoleon Gulfs of Lake Victoria, hippo grass has become common in littoral waters that were previously congested with water hyacinth (Eichhornia crassipes; Masifwa et al., 2001; Omondi and Kusewa, 2006). In these systems, hippo grass proliferates by colonizing mats of water hyacinth, eventually outcompeting it for nutrients and light (Omondi and Kusewa, 2006). Its expansion in lakes where Nile perch are abundant could hinder the use of wetlands as a refuge for native fish species, and there may be some degree of facilitation between the spread of these two invaders. In Lake Nabugabo, which has not experienced water hyacinth invasion to date, it is hypothesized that the demise of haplochromine cichlids following the Nile perch introduction released hippo grass from control; haplochromines had previously hindered macrophyte establishment through their constant disturbance of the substrate (Witte et al., 1992). However, haplochromine populations collapsed in the early 1980s (Kaufman, 1992; Ogutu-Ohwayo, 1993), and it was not until the mid-1990s that the expansion of hippo grass occurred (Kateyo, 2006; Paterson and
Chapman, 2009). A time lag between these events is possible, but unlikely given that hippo grass is extremely prolific and fast-growing, and the recent recovery of some haplochromine populations (Chapman et al., 2003) has had no apparent effect on the hippo grass expansion (Paterson and Chapman, 2009). Further research is required to draw any causal link between haplochromine abundance and the success of hippo grass establishment. A better understanding of the mechanisms underlying hippo grass expansion throughout the Lake Victoria basin is essential to its effective management and the protection of wetland refugia.

\section{CONCLUSIONS}

This study demonstrates the role of edge-related gradients in shaping refuge communities, lending further support to the value of hypoxic habitats as refugia from introduced predators. By establishing a link between physico-chemical gradients and peak refugia, this research points to the importance of invader-edge dynamics in determining the outcome of interactions between introduced predators and resident prey.

Wetland habitats throughout the Lake Victoria basin are being increasingly threatened by human impacts such as eutrophication and burning to convert to agricultural land (Bikangaga et al., 2007; Chapman et al., 2008). The identification of peak refugia in the wetlands of Lake Nabugabo permits more spatially explicit management approaches, such as the development of secure buffer zones surrounding wetland edges. Despite being recently designated as a Ramsar site by the Convention on Wetlands of International Importance, little effort and resources are being invested in the protection of these habitats, although they have been shown to be critical in the maintenance of native biodiversity. Failing adequate protection of this critical habitat, the deployment of artificial refugia may serve as a viable management alternative (Rahel et al., 2008). However, a recent comparative study of this strategy to promote coexistence between invasive western mosquitofish (Gambusia affinis) and native Barrens topminnow (Fundulus julisia) found no evidence for this as a feasible option (Westhoff et al., 2013). Hippo grass poses an additional threat to wetland habitats and the long-term viability of native fish populations. The findings presented herein suggest that the effect of hippo grass on wetland 
dynamics could be reduced if the hippo grass band were maintained below approximately $30 \mathrm{~m}$ width; above this level, there is little difference in the mean physico-chemical and biological features of wetland habitats. Future research should therefore be focused on (1) understanding the mechanisms that underlie the proliferation of hippo grass so that it may be controlled, and (2) the development of alternative uses of this macrophyte, providing an incentive to local stakeholders to play a role in the control of hippo grass (e.g. the use of water hyacinth as a biogas, fertilizer and construction material; Gunnarsson and Peterson, 2007).

\section{ACKNOWLEDGEMENTS}

Permission to conduct this research was granted by the Uganda National Council for Science and Technology and the McGill University Animal Care Committee. Research funding was provided by the Natural Science and Engineering Research Council of Canada, National Geographic, and the McGill University School of Environment. We extend special thanks to C. Chapman, D. Twinomuguisha, M. Farrell, M. Luke, J. Mutebi, G. Kiberu, J. Sseguya and S. Gray for their participation in field data collection in Lake Nabugabo, Uganda.

\section{REFERENCES}

Ayala JR, Rader RB, Belk MC, Schaalje GB. 2007. Ground-truthing the impact of invasive species: spatio-temporal overlap between native least chub and introduced western mosquitofish. Biological Invasions 9: 857-869.

Balirwa JS, Chapman CA, Chapman LJ, Cowx IG, Geheb K, Kaufman L, Lowe-McConnell RH, Seehausen O, Wanink JH, Welcomme RL, Witte F. 2003. Biodiversity and fishery sustainability in the Lake Victoria basin: an unexpected marriage? Bioscience 53: 703-715.

Bikangaga S, Picchi MP, Focardi S, Rossi C. 2007. Perceived benefits of littoral wetlands in Uganda: a focus on the Nabugabo wetlands. Wetlands Ecology and Management 15: 529-535.

Chapman LJ, McKenzie D, 2009. Behavioral responses and ecological consequences. In Hypoxia in Fishes, Richards JG, Farrell AP, Brauner CJ (eds). Elsevier: San Diego; 25-77.

Chapman LJ, Chapman CA, Chandler M. 1996a. Wetland ecotones as refugia for endangered fishes. Biological Conservation 78: 263-270.

Chapman LJ, Chapman CA, Ogutu-Ohwayo R, Chandler M, Kaufman L, Keiter AE. 1996b. Refugia for endangered fishes from an introduced predator in Lake Nabugabo, Uganda. Conservation Biology 10: 554-561.

Chapman LJ, Chapman CA, Nordlie FG, Rosenberger AE. 2002. Physiological refugia: swamps, hypoxia tolerance and maintenance of fish diversity in the Lake Victoria region. Comparative Biochemistry and Physiology Part A 133: 421-437.
Chapman LJ, Chapman CA, Schofield PJ, Olowo JP, Kaufman L, Seehausen O, Ogutu-Ohwayo R. 2003. Fish faunal resurgence in Lake Nabugabo, East Africa. Conservation Biology 17: 500-511.

Chapman LJ, Chapman CA, Kaufman L, Witte F, Balirwa J. 2008. Biodiversity conservation in African inland waters: lessons of the Lake Victoria region. Verhandlungen der Internationalen Vereinigung für theoretische und angewandte Limnologie 30: 16-34.

Clavero M, Garcia-Berthou E. 2005. Invasive species are a leading cause of animal extinctions. Trends in Ecology \& Evolution 20: 110.

Closs GE, Lake PS. 1996. Drought, differential mortality and the coexistence of a native and an introduced fish species in a south east Australian intermittent stream. Environmental Biology of Fishes 47: 17-26.

Courchamp F, Chapuis JL, Pascal M. 2003. Mammal invaders on islands: impact, control and control impact. Biological Reviews 78: 347-383.

Cox JG, Lima SL. 2006. Naiveté and an aquatic-terrestrial dichotomy in the effects of introduced predators. Trends in Ecology \& Evolution 21: 674-680.

Crowder LB, Cooper WE. 1982. Habitat structural complexity and the interaction between bluegills and their prey. Ecology 63: $1802-1813$.

Fish GR. 1956. Some aspects of the respiration of six species of fish from Uganda. Journal of Experimental Biology 33 186-195.

Greenwood PH. 1965. The cichlid fishes of Lake Nabugabo, Uganda. Bulletin of the British Museum of Natural History 12: $315-355$.

Gunnarsson CC, Peterson CM. 2007. Water hyacinths as a resource in agriculture and energy production: a literature review. Waste Management 27: 117-129.

Hall SR, Mills EL. 2000. Exotic species in large lakes of the world. Aquatic Ecosystems Health \& Management 3: 105-135.

Kateyo EM. 2006. Biodiversity of an interface zone of a nutrient deficient lake (Nabugabo) in Uganda: macrophytes. African Journal of Ecology 45: 130-134.

Kaufman L. 1992. Catastrophic change in species-rich freshwater ecosystems. Bioscience 42: 846-858.

Kestrup M, Ricciardi A. 2009. Environmental heterogeneity limits the local dominance of an invasive freshwater crustacean. Biological Invasions 11: 2095-2105.

Leighton PA, Horrocks JA, Krueger BH, Beggs JA, Kramer DL. 2008. Predicting species interactions from edge responses: mongoose predation on hawksbill sea turtle nests in fragmented beach habitat. Proceedings of the Royal Society B: Biological Sciences 275: 2465-2472.

Levine JM, Vila M, Antonio C, Dukes JS, Grigulis K, Lavorel S. 2003. Mechanisms underlying the impacts of exotic plant invasions. Proceedings of the Royal Society B: Biological Sciences 270: 775-781.

Masifwa WF, Twongo T, Denny P. 2001. The impact of water hyacinth, Eichhornia crassipes (Mart) Solms on the abundance and diversity of aquatic macroinvertebrates along the shores of northern Lake Victoria, Uganda. Hydrobiologia 452: 79-88.

Nilsson GE, Ostlund-Nilsson S. 2004. Hypoxia in paradise: widespread hypoxia tolerance in coral reef fishes. Proceedings of the Royal Society B: Biological Sciences 271: S30-S33.

Ogutu-Ohwayo R. 1993. The effects of predation by Nile perch, Lates niloticus L., on the fish of Lake Nabugabo, with suggestions for conservation of endangered endemic cichlids. Conservation Biology 7: 701-711.

Omondi R, Kusewa M, 2006. Macrophytes of Lake Victoria and succession after invasion of water hyacinth. In Proceedings of the 11th World Lakes Conference, Nairobi; 600-602. 
Paterson JA, Chapman LJ. 2009. Fishing down and fishing hard: ecological change in the Nile perch of Lake Nabugabo, Uganda. Ecology of Freshwater Fishes 18: 380-394.

Rahel FJ, Bierwagen B, Taniguchi Y. 2008. Managing aquatic species of conservation concern in the face of climate change and invasive species. Conservation Biology 22: 551-561.

Reardon EE, Chapman LJ. 2008. Reproductive seasonality in a swamp-locked African cichlid. Ecology of Freshwater Fish 17: $20-29$.

Ricciardi A. 2007. Are modern biological invasions an unprecedented form of global change? Conservation Biology 21: 329-336.

Ricciardi A, Rasmussen JB. 1999. Extinction rates of North American freshwater fauna. Conservation Biology 13: 1220-1222.

Robb T, Abrahams MV. 2003. Variation in tolerance to hypoxia in a predator and prey species: an ecological advantage of being small? Journal of Fish Biology 62: 1067-1081.

Rosenberger AE, Chapman LJ. 1999. Hypoxic wetland tributaries as faunal refugia from an introduced predator. Ecology of Freshwater Fishes 8: 22-34.

Rosenberger AE, Chapman LJ. 2000. Respiratory characters of three species of haplochromine cichlids: implications for use of wetland refugia. Journal of Fish Biology 57: 483-501.

Sala OE, Chapin III FS, Armesto JJ, Berlow E, Bloomfield J, Dirzo R, Huber-Sanwald E, Huenneke LF, Jackson RB, Kinzig A, et al. 2000. Global biodiversity scenarios for the year 2100. Science 287: 1770-1774.

Schofield PJ, Chapman LJ. 1999. Interactions between Nile perch, Lates niloticus, and other fishes in Lake Nabugabo, Uganda. Environmental Biology of Fishes 55: 343-358.
Schofield PJ, Chapman LJ. 2000. Hypoxia tolerance of introduced Nile perch: implications for survival of indigenous fishes in the Lake Victoria basin. African Zoology 35: 35-42.

Seehausen O. 1996. Lake Victoria Rock Cichlids: Taxonomy, Ecology and Distribution. Verduijn Cichlids: Zevenhuizen, Netherlands.

Seehausen O, Witte F, Katunzi EF, Smits J, Bouton N. 1997. Patterns of the remnant cichlid fauna in southern Lake Victoria. Conservation Biology 11: 890-904.

Stager JC, Westwood J, Grzesik D, Cumming BF. 2005. A 5500-year environmental history of Lake Nabugabo, Uganda. Palaeogeography, Palaeoclimatology, Palaeoecology 218: $347-354$.

Trumpickas J, Mandrak NE, Ricciardi A. 2011. Nearshore fish assemblages associated with introduced predatory fishes in lakes. Aquatic Conservation: Marine and Freshwater Ecosystems 21: 338-347.

Westhoff JT, Watts AV, Mattingly HT. 2013. Efficacy of artificial refuge to enhance survival of young Barrens topminnows exposed to western mosquitofish. Aquatic Conservation: Marine and Freshwater Ecosystems 23: 65-76.

Witte F, Goldschmidt T, Wanink J, Oijen M, Goudswaard K, Witte-Maas E, Bouton N. 1992. The destruction of an endemic species flock: quantitative data on the decline of the haplochromine cichlids of Lake Victoria. Environmental Biology of Fishes 34: 1-28.

Zaret TM, Paine RT. 1973. Species introduction in a tropical lake. Science 182: 449-455. 